\title{
Plato and Equality for Women across Social Class
}

Coleen P. Zoller

This essay will marshal evidence for Plato's extension of equal education and professional opportunity to all women, including artisan women who are not his ideal city's philosopher-queens. I examine the explicit commentary in the Republic, Timaeus, and Laws about women in artisan professions, and I link it together with the three of the core principles advanced in the Republic, particularly (1) the principle of specialization $(R .369 \mathrm{~b}-370 \mathrm{c}),(2)$ the principle of irrelevant reproductive differences $(R .454 \mathrm{~b}-\mathrm{e}, 456 \mathrm{~b})$, and (3) the principle of children's potential $(R .415 \mathrm{a}-\mathrm{c}$, $423 \mathrm{c}-\mathrm{d})$ that arises from the myth of metals. Plato uses his Socrates and the Athenian to argue against gender discrimination because it violates these principles. Plato offering a theory of equal opportunity for women across all classes ought to be highlighted as one of the central achievements of the Republic.

\section{Do Plato's Proposals for Sex Equality Extend to Women of the Producer Class?}

With the exception of a minority of scholars who ignore or ridicule the proposal ${ }^{1}$, it is generally agreed that in the Republic Plato's Socrates contends that, like men, women can merit inclusion in the elite group of philosopher-monarchs $(R .456 \mathrm{a}-\mathrm{b}, 466 \mathrm{c}-\mathrm{d}$; see also $R$. 540c). ${ }^{2}$ Many commentators assume that Plato's provision of equal education and professional opportunity extends only to women with potential to become philosopherqueens. ${ }^{3}$ Far less scholarly attention has been paid, however, to the question of whether

${ }^{1}$ I. M. Crombie, An Examination of Plato's Doctrines (New York: Humanities Press, 1962), p. 100, Leo Strauss, The City and Man (Chicago: University of Chicago Press, 1964), and Allan Bloom, trans., The Republic of Plato, with Notes and Interpretive Essay (New York: Basic Books, 1968) reject the seriousness of Plato's claims about equality of education and opportunity for women and men. See Bluestone, Women and the Ideal Society, for a catalog of such commentators.

${ }^{2}$ See Appendix A.

${ }^{3}$ Crossman, Plato Today, 125; Annas, 'Plato's Republic and Feminism', p. 315; Okin, 'Philosopher Queens', pp. 359-60; Smith, 'The Logic of Plato's Feminism', pp. 8-9; John Darling, 'Are Women Good Enough? Plato's Feminism Re-Examined', Journal of Philosophy of Education, 20 (1986), pp. 123-8, p. 123; Vlastos, 'Was Plato a Feminist?', p. 12; Smith, 'Plato, Irony, and Equality', p. 46; 
Plato's proposals for sex equality extend to the artisan women who are not philosopherqueens.

The commentators who assume his proposals extend only to philosopher-queens take Plato as silent concerning any overhaul of the traditional lives of the artisan class. There is a divide among these scholars between those who are bothered by Plato's alleged exclusion of working-class women and those who do not express such a concern. Bluestone is critical of scholars who believe equality of education and opportunity are open only to elite women (not to female artisans) and who express "no concern that Plato spoke of equality only for an elite group". ${ }^{4}$ Similarly, Chadwick rightly contends that if Plato only wants equality of opportunity for guardian women, he too would be guilty like many present-day feminists of elitism —of only being concerned with women of one class. ${ }^{5}$ I agree that if Plato did think equal education and opportunity were only applicable to guardian women, then we ought to be troubled by his elitism.

However, I find myself at odds with those who do not recognize Plato's extension of equal education and opportunity to all women, including artisan women. Bluestone's treatment stands out because she understands clearly that Plato's principles commit him to equality of education and professional opportunity for all women, and she herself notes that Averroës reads Plato as extending his proposals about equality for women to the women of every class ${ }^{6}$, but she does not see Plato as extending sex equality to artisans because she takes Plato to be totally silent about artisan women. ${ }^{7}$ I will show that Plato is, in fact, not silent about female artisans and Averroës was not mistaken after all when he wrote that for Plato

Natalie Harris Bluestone, Women and the Ideal Society: Plato's Republic and Modern Myths of Gender (Amherst: The University of Massachusetts Press, 1987), pp. 72, 85. See also H. D. Rankin, Plato and the Individual (London: Methuen, 1964) and Martin, 'Sex Equality and Education', pp. 294, 297.

${ }^{4}$ Bluestone, Women and the Ideal Society, p. 72.

${ }^{5}$ Ruth Chadwick, 'Feminism and Eugenics: The Politics of Reproduction in Plato's Republic', in Polis and Politics: Essays in Greek Moral and Political Philosophy, ed. Andros Loizou and Harry Lesser (Aldershot: Avebury, 1990), pp. 101-10, p. 106.

${ }^{6}$ Natalie Harris Bluestone, 'Why Women Cannot Rule: Sexism in Plato Scholarship' in Feminist Interpretations of Plato, ed. Tuana, pp. 109-30, pp. 113-4.

${ }^{7}$ Smith, 'The Logic of Plato's Feminism', p. 9; Bluestone, Women and the Ideal Society, p. 18. 
"women are essentially on the same level with men in respect to civic activities in the same classes". 8

If Plato had explored the topic of gender and justice more extensively, it would have been easier for Plato's audience to grasp what Averroës recognizes, that Plato believes what is best for the city is for each class to offer girls the same education and professional opportunity as their male peers. As I will show, Plato is an early initiator of the rejection of gender discrimination, and the project of demonstrating the value of equal education and professional opportunity for girls and women across all social classes begins with Plato.

In section II, I will focus on the status of female artisans in the Laws, Republic, and Timaeus. These explicit comments make clear that Plato was indeed considering female artisan in the context of his proposals about equal education and professional opportunity. This section will examine the central role of theoretical principles in Plato's thinking about women's work in the Republic. Specifically, as we shall see in this section, the principle of specialization (R. 369b-370c) and the principle that reproductive differences are irrelevant to non-reproductive occupations (R. 454b-e, 456b) apply as much to female artisans as to the elite female guardians. In other words, the logic Plato has Socrates use to defend the need for some women to be guardians alongside some men is explicitly applied to all women, even those who are not philosopher-queens.

Next, in Section III I will examine the relevance of a principle that arises in the myth of metals, which I refer to as the principle of children's potential (R. $415 \mathrm{a}-\mathrm{c}, 423 \mathrm{c}-\mathrm{d})$. This principle, that children are not necessarily of their parents' 'metal', has important implications for the educational program of the Republic. The myth of metals takes it for granted that a state-sponsored educational program must operate across all classes in order to discover each child's nature and potential contribution to the city's good. As we shall see, state-sponsored professional child-care is necessary for adhering to the principle of specialization and the principle of the irrelevance of reproductive difference for nonreproductive labor. In other words, the myth of metals requires and presumes equal education and opportunity across all social classes.

\footnotetext{
${ }^{8}$ Averroës Commentary on Plato's Republic, ed. E.I.J. Rosenthal (Cambridge: Cambridge University Press, 1966), 454, p. 164. Emphasis added.
} 


\section{Plato's extension of equal education and professional opportunity to all women}

In both the Laws and Republic Plato explores the status of female artisans as well as the benefits that accrue to the state from an educational system that does not discriminate based upon sex/gender. Let's look into Plato's commentary concerning professional opportunity for working-class women.

Let's turn first to the Laws, Plato's final dialogue. There Plato has the Athenian claim that all boys and girls should imitate Athena; he writes, "Our boys and girls should imitate [Athena's] example wholeheartedly, and prize the gift which the goddess made them" (L. 796c; cf. L. 626d). After introducing the notion of imitating Athena, Plato has the Athenian advocate for raising all boys and girls the same way (L. 804d-805b), and shortly thereafter he reminds us that girls who have not been given equal opportunity with respect to military training "wouldn't be able to take up shield and spear and copy Athena" (L. 806b). Plato easily uses Athena's female warrior status to help him advocate for women to be included in the military. And given Athena's association with wisdom, she persists as a powerful patroness for the city of Athens where Plato first advanced the notion that some women could be wise enough to lead the city alongside some qualified men (R. 456a-b).

Yet, we must also remember that Athena is the goddess of craft too. Thus, Plato fittingly has the Athenian employ the theme of imitating Athena while recommending that "in education and everything else, the female sex should be on the same footing as the male" (hôs dei paideias te kai tôn allôn hoti malista koinônein to thêlu genos hemin tôi tôn arrenôn genei) (L. 805d; emphasis added). Athena is known as not only the patron goddess of Athens but also the patroness of various artisans and crafts, especially weaving (cf. L. 920d). ${ }^{9}$ In the Classical period, there were regular occurrences of the epithet Athena Ergane, ${ }^{10}$ the patron goddess of manual work. So, in the Laws Plato uses the motif of imitating Athena to recommend that all little girls be educated and trained alongside their male counterparts, whether they will copy Athena with their talent for wisdom, warfare, weaving, or another

\footnotetext{
${ }^{9}$ Cf. Smp. 197b; Prt. 321d-322a; Criti. 109c. See also Pomeroy, Goddesses, pp. 4-5.

${ }^{10}$ Jon D. Mikalson, Athenian Popular Religion (Chapel Hill: The University of North Carolina Press, 1983), p. 141 n. 21.
} 
craft. Thus, Plato's explicit extension of equal education and professional opportunity to all women across social class is evident in the Laws.

How does this position in the Laws compare to the earlier Republic? Although Plato spends much more time on the issue in the Republic and there he relies upon more theoretical framework in expressing his position, the position mirrors the extension of equal education and professional opportunity for all women expressed in the Laws. Let's examine the nuances of the position taken in the Republic where key principles are established, namely, the principle of specialization and the principle of the irrelevance of reproductive difference for non-reproductive labor.

Plato has Socrates claim that cities are founded because people believe that living "together as partners and helpers" is best for themselves $(R .369 \mathrm{c})$. From this notion springs the Republic's principle of specialization, that each person should work for the common good of all, contributing what each is naturally suited to do (R. 369b-370c). The principle of specialization is one of the main political principles governing the political activity of the city. At the point where the principle of specialization is introduced, Plato has Socrates envision the principle of specialization applying to "each of them" (hêna hekaston toutôn) (R. 369e1-2; see also R. 433a, 453b5) in the community rather than only some of the people in the community. And later in the Republic he explicitly applies the principle of specialization to women not just men $(R .433 \mathrm{~d})$ as he holds the principle of specialization up as the key ingredient for a just community (R. 433c-e).

Plato depicts Socrates as keenly aware $(R .450 \mathrm{c}-\mathrm{d}, 452 \mathrm{a}-\mathrm{c})$ that the proposals he offers in Book V concerning equality for women are likely to be an object of ridicule for those to whom they seem "contrary to custom" $(R .452 \mathrm{a})$, and this remains largely true even today. Interestingly, Plato has Glaucon encourage Socrates to proceed with his defense, reminding him that his "audience isn't inconsiderate, incredulous, or hostile" (R. 450d). And Socrates urges everyone to push past the jokes and the fear of being ridiculed in order to consider properly this revolutionary idea, and he highlights how important it is for him to help his interlocutors search for the truth on this philosophical matter (R. 450e-451a). Socrates is so committed to persuading any doubters that he invites anyone to question them "about whether female human nature can share all the tasks of that of the male, or none of them, or some but not others" (poteron dunatê phusis hê anthrôpinê hê thêleia têi tou arrenos genous 
koinônêsai eis hapanta ta erga ê oud' eis hen, ê eis ta men hoi ate, eis de ta ou) (R. 452e453a). So, Socrates and Glaucon agree to represent the objections of the doubter (R. 453a-b).

I disagree with Annas's claim that Plato does nothing to refute a sex segregationist's objection. ${ }^{11}$ Plato has Socrates acknowledge the existence of sexual differences between men and women only to warn his audience not to get hoodwinked by this fact (R. 454a-b). Socrates offers an extended argument that reproductive ability to bear or beget is irrelevant to all nonprocreative endeavors, including but not limited to occupations such as managing the city.

He writes, “...it's apparent that they differ only in this respect, that the females bear children while the males beget them..." (R. 454d). Sex segregationists fail to see that their logic would not only restrict all women to specializing solely in pregnancy, childbirth, and breast-feeding; it would also restrict all men from doing another job merely because of their ability to beget children. And of course a polis must do more than bear and beget if it is to survive. $^{12}$

This principle of the irrelevance of sexual differences accounts entirely for why Plato believes not only that men and women should share all the work necessary for survival like farming, carpentry, and so on, but also that men and women should share the work of raising children. In the context of discussing life for the Kallipolis's guardians, Plato has Socrates say:

You agree, then, that the women and men should associate with one another in education, in things having to do with children, and in guarding the other citizens in the way we've described; that both when they remain in the city and when they go to war, they must guard together and hunt together like dogs and share in everything as far as possible; and that by doing so they'll be doing what's best and not something contrary either to woman's nature as compared with man's or to the natural association of men and women with one another ( $R$. 466c-d; emphasis added; see also R. 540c.). ${ }^{13}$

Plato deserves credit for realizing that qualified women leading alongside their qualified male peers is neither unnatural for women themselves nor for the dynamic between the sexes. And it is revolutionary even by today's standards to believe that that gender is

\footnotetext{
${ }^{11}$ Annas, 'Plato's Republic and Feminism', p. 310.

${ }^{12}$ McKeen, 'Why Women Must Guard', pp. 533-4.

${ }^{13}$ G. M. A. Grube, trans., Republic, rev. C.D.C. Reeve, in Plato Complete Works, ed. John M. Cooper (Indianapolis: Hackett Publishing, 1997), pp. 971-1223. I will rely on Grube's translation throughout this paper.
} 
irrelevant to the capacity for child-care $(R .460 \mathrm{~b}, 466 \mathrm{c}) .{ }^{14}$ Furthermore, just earlier in the Republic Plato's Socrates asserts that state-sponsored professional child-care makes it possible for parents to work $(R .460 \mathrm{~d})$ and that there should no double standard at all concerning the rules of sexual morality ( $R$. 459d, 460d-461c). When Plato's Socrates proclaims that gender is even irrelevant to the job of caring for children $(R .460 \mathrm{~b}, 466 \mathrm{c})$, he is introducing what will become a core principle of feminism. As Okin writes, "The real significance of the treatment of the woman question in Republic $\mathrm{V}$ is that it is one of the very few instances in the history of thought when the biological implications of femaleness have been clearly separated from all the conventional, institutional, and emotional baggage that has usually been identified with them". ${ }^{15}$

After showing that reproductive differences are irrelevant to the work of managing the city, Plato has Socrates make a set of claims about women's professional capacities at Republic 455e-456a that merit greater attention. This passage makes explicit that Plato's Socrates envisions women in artisan occupations too, but unfortunately it has been ignored by commentators who assume Plato's proposals extend only to guardians. ${ }^{16}$ However, Martin, Reeve, Santas, Harry and Polansky, and Rowett are exceptions. I join them in seeing the tremendous significance of 455e-456a. There Plato has Socrates explicitly indicate that some women will have the nature of a doctor $(R .455 \mathrm{e})$, that some women will have the nature of a musician $(R .455 \mathrm{e})$, and that some women will be athletic or warriors $(R .455 \mathrm{e}-456 \mathrm{a})$. Given that doctors were typically grouped alongside other craftsmen ${ }^{17}$, the case of the female doctor has special significance here. This passage flatly contradicts Bluestone's claim that Plato “only mentions women's abilities in connection with those who would be Philosopher-

${ }^{14}$ Pace Sue Blundell, Women in Ancient Greece (Cambridge, MA: Harvard University Press, 1995), p. 185, who mistakenly indicates that Plato believes child-care is women's work.

${ }^{15}$ Okin, 'Philosopher Queens', p. 358.

${ }^{16}$ Martin, 'Sex Equality and Education', p. 286, C.D.C. Reeve, 'The Naked Old Women in the Palaestra', in Plato's Republic: Critical Essays, ed. Richard Kraut (Lanham, MD: Rowman and Littlefield, 1997), pp. 129-41, p. 131, Santas, 'Justice, Law, and Women', Harry and Polansky, 'Plato on Women's Natural Ability', p. 271, and Catherine Rowett, 'Why the Philosopher Kings Will Believe the Noble Lie', Oxford Studies in Ancient Philosophy, 50 (2016), pp. 67-100, p. 95. Arlene Saxonhouse, 'The Philosopher and the Female in the Political Thought of Plato', in Feminist Interpretations of Plato, ed. Tuana, pp, 67-85, p. 72, does not ignore it but instead contends that this part of the text "must be seen as comic in intent."

${ }^{17}$ Ste. Croix, Class Struggle, p. 271. 
Queens". ${ }^{18}$ Here Plato's Socrates applies what Martin calls the "Postulate of Specialized Natures"19 - that each person is born with greater capacity for one occupation than for others (R. 370a-b) - to all women not just guardian women. So, some women will be apt for leadership, while others are fit for soldiering, and still others are suited to be producers. ${ }^{20}$ Plato's principle of specialization tells us that it damages the polis if any individual is excluded from the occupation for which his/her nature is suited (R. 433a-b), and his theory of justice determines that this harm is unjust. Therefore, Plato recognizes it as unjust when gender discrimination bars women from occupations for which they have the appropriate nature.

Beyond Socrates's mention of women's capacity for medicine, music, and the military, Plato's Socrates clearly knows his argument also applies to cobbling. He and Glaucon have already gone over why all that matters to being a cobbler is having a cobbler's nature rather than any irrelevant physical features such as being long-haired or bald $(R .454 \mathrm{c})$. Once they have covered the irrelevance of reproductive difference to the natures fit for ruling, medicine, music, and soldiering, it becomes easy to agree that reproductive difference is also irrelevant to the nature fit for cobbling. More importantly, reproductive difference would be irrelevant to any of the crafts that Plato's Socrates mentions in the context of the principle of specialization: farming, building, weaving, cobbling, and medicine (R. 369d).

I interpret Plato as a feminist in part because of his "attempts to demonstrate that biological differences are irrelevant to all but reproductive activities," to use Bluestone's words. ${ }^{21}$ And indeed, Plato has Socrates make that explicit; he writes, "Then there is no way of life concerned with the management of the city that belongs to a woman because she's a woman or to a man because he's a man, but the various natures are distributed in the same way in both creatures. Women share by nature in every way of life just as men do..." (ouden ara estin...epitêdeuma tôn polin dioikountôn gunaikos dioti gunê, oud' andros dioti anêr,

\footnotetext{
${ }^{18}$ Bluestone, Women and the Ideal Society, p. 98.

${ }^{19}$ Martin, ‘Sex Equality and Education', p. 283.

${ }^{20}$ See also Santas, 'Justice, Law, and Women', p. 31, Catherine McKeen, 'Why Women Must Guard and Rule in Plato's Kallipolis', Pacific Philosophical Quarterly, 87 (2006), pp. 527-48, p. 538, and Patrick Coby, 'Minding Your Own Business: The Trouble with Justice in Plato's Republic', Interpretation, 31 (2003), pp. 37-58, p. 54.

${ }^{21}$ Bluestone, Women and the Ideal Society, p. 95.
} 
all' homoiôs diesparmenai hai phuseis en amphoin toin zôoin, kai pantôn men metexei gunê epitêdeumatôn kata phusin...) (R. 455d; emphases added). And Republic 455d-e does not merely claim that women can have a nature suited for ruling or the military. Most commentators have gone wrong by ignoring the evidence at 455e-456a that Plato's Socrates explicitly includes artisan women when he imagines equal professional opportunity for women and men. As Martin writes, “...there is in Plato's Just State...equality of role opportunity for men and women: it is possible for members of either sex to be suited by nature for the role of artisan, auxiliary, or ruler..."22 Without qualification, Republic 455d-e declares that individual women can merit a position alongside individual men in every way of life.

One might object that the physical nature of women as a class (characterized by the so-called "average woman") is not suited for occupations that involve heavy manual labor because on average women are smaller and have smaller muscle mass. Plato's Socrates admits that women as a class are physically weaker than men as a class ( $R .451 \mathrm{e}, 455 \mathrm{~d}-\mathrm{e})$. Of course, military service includes tasks with heavy physical demands. Yet, Socrates insists that at least some women will have a nature suitable even for physically demanding work ( $R$. 455e-456a). Thus, there is nothing about being a woman that rules out having the capacity for physically demanding work. At most, a higher percentage of men will be suitable for such jobs. Furthermore, earlier Socrates, Adeimantus, and Glaucon discuss the weakness of some bodies making them a better fit for retail work (R. 371c-d). That passage does not specify gender, but the interlocutors are either thinking of all people or they are defaulting to think of men. So, it is important to note that at Republic 371c-d they appear as interested in the physical weakness of male bodies as they are in the physical weakness of female bodies as a disqualifier for certain jobs.

The interlocutors can acknowledge that women as a class are physically weaker than men as a class without contradicting the claim that being a woman does not by itself disqualify anyone for any type of job. What is crucial here is the ability to distinguish between individual women and women as a class. And it is Glaucon who astutely introduces that important distinction. At 455d, Plato has Glaucon say, "It's true that one sex is much superior

\footnotetext{
${ }^{22}$ Martin, 'Sex Equality and Education', p. 286.
} 
to the other in pretty well everything, although many women are better than many men in many things." As a result of this, Glaucon rejects the notion that all occupations should be assigned to men $(R .455 \mathrm{e})$. At that point, Socrates discusses women with natures of doctors, musicians, athletes/warriors, and philosophers ( $R .455 \mathrm{e}-456 \mathrm{a})$. One of the most fundamental aspects of Plato's feminism is this recognition that an individual woman may have any nature that an individual man could have, be it that of a political leader, a warrior, a doctor, a musician, a cobbler, a carpenter, etc.

It is on account of their ability to see the various possible natures for individual women (and men) that Socrates and Glaucon conclude that "we're not legislating impossibilities or indulging in mere wishful thinking, since the law we established is in accord with nature. It's rather the way things are at present that seems to be against nature" (R. 456c). Here Plato has Socrates put to rest the concerns Polemarchus and Glaucon raised over this "first wave" of opposition to his proposals of equal education and opportunity for women and men. Although Annas claims that Plato does not present the inequality of the sexes in Athens as an injustice ${ }^{23}$, I interpret this critical comment about "the way things are at present" as an indication that Plato's Socrates believes the conventional treatment of women in ancient Athens fails to meet the standard of justice he lays out in the Republic.

Furthermore, introducing the crafts of medicine and music in his discussion begins to open the door to consideration of activities that require skill beside physical strength. Harry and Polansky take the most important aspect of Plato's project to be his effort to "limit the significant natural differences between males and females to body-type". ${ }^{24}$ It is helpful that Plato has Socrates include weaving when talking about the occupations the city needs. While not solely performed by women, women are frequently associated with weaving (see $R$. 455c); so in explaining the principle of specialization, Plato's Socrates even gives one instance of an artisan occupation that already involved women. Consequently, when Plato has Socrates conclude in the Republic that women and men share in every way of life, it should be interpreted as an endorsement of equal education and training even for artisan

\footnotetext{
${ }^{23}$ Annas, 'Plato's Republic and Feminism', p. 314.

${ }^{24}$ Harry and Polansky, 'Plato on Women's Natural Ability', p. 263.
} 
women. Discussing women's participation in every way of life would be rather strange if Plato only had ruling and the military in mind.

Finally, a passage at Timaeus 18c shores up this reading. Although the Timaeus's brief attempt at a summary of the Republic's conversation (set dramatically on the prior day) is not at all thorough, it reinforces Republic 455e-456a. There Plato has Socrates say, "And in fact we even made mention of women. We said that their natures should be made to correspond with those of men, and that all occupations, whether having to do with war or with the other aspects of life, should be common to both men and women" (ta epitêdeumata panta koina kata te polemon kai kata tên allên diaitan doteon pasais) (Ti. 18c; emphasis added). ${ }^{25}$ Here Plato's Socrates takes it as an established conclusion of their discussion in the Republic that indeed all occupations would be open to both men and women. This passage adds force to my claim that Plato's position in the Republic mirrors that of the Laws, which holds that all professions should be open to both men and women, not just guarding but all others too (L. 829e, 882c).

Having examined the applicability of the principle of specialization and the principle of the irrelevance of sexual difference to non-reproductive work, let us now draw out the consequences of linking these principles to the the myth of metals.

\section{Connecting the Principle of Specialization and the Myth of Metals}

After the interlocutors question how guardians will be selected, Plato has Socrates introduce the myth of metals to make a radical proposal about equal opportunity for all. They agree that guardians will be appointed from the pool of young people who succeed when tested "as a child, youth, and adult" ( $R .413 \mathrm{e}-414 \mathrm{a})$. The thorough testing they have in mind for guardians looks for graciousness in everything, rhythm and harmony, resistance to being "put under a spell," and being a good guardian of oneself and the music and poetry one has learned (R. 413d-e). However, they confess that they have not gone through the details of this selection process $(R .414 \mathrm{a})$. Socrates then tells an old Phoenician story that he thinks it would be difficult to get people to believe. Plato writes:

\footnotetext{
${ }^{25}$ Donald J. Zeyl, trans., Timaeus, in Plato Complete Works, ed. Cooper, pp. 1224-91.
} 
'All of you in the city are brothers,' we'll say to them in telling our story, 'but the god who made you mixed some gold into those who are adequately equipped to rule, because they are most valuable. He put silver in those who are auxiliaries and iron and bronze in the farmers and other craftsmen. For the most part you will produce children like yourselves, but, because you are all related, a silver child will occasionally be born from a golden parent, and vice versa, and all the others from each other. So the first and most important command from the god to the rulers is that there is nothing that they must guard better or watch more carefully than the mixture of metals in the souls of the next generation. If an offspring of theirs should be found to have a mixture of iron or bronze, they must not pity him in any way, but give him the rank appropriate to his nature and drive him out to join the craftsmen and farmers. But if an offspring of these people is found to have a mixture of gold or silver, they will honor him and take him up to join the guardians or the auxiliaries...' (R. 415a-c; emphasis added).

At the heart of the myth of metals is the concept that a child's nature cannot be inferred from the parents' nature. I call this the principle of children's potential. Children each have their own nature and potential, which is not necessarily the same as their parents'. Consequently, the myth takes a program for equal education and opportunity across social class as an established necessity. Yet, it has been a struggle for his audience to pick up on the true nature of Plato's project in the myth of metals, which focuses on the centrality of equal opportunity for a just society.

Here I aim to illuminate the radical nature of Plato's vision of equal opportunity. I concur with Rowett that the myth "is designed to deliver greater fairness and equality of opportunity, to prevent prejudice or privilege arising from noble birth or wealth or any other unfair advantages, and to facilitate social mobility". ${ }^{26}$ With this in mind, let's examine Plato's Socrates's assertion of the principle of children's potential in the myth of metals, which has important implications for both child-care and education throughout the city.

Long after the myth of metals we learn that the babies born to guardians will be raised in a rearing pen staffed by the men and women who have the nature best suited for child-care (R. 460b-d), as I mentioned in Section II. Plato has Socrates say very little about even the guardian rearing pen, and he does not explicitly describe the system for nurturing babies born to the producer class. Yet, there are two reasons for Plato to regard professional child-care and education for the children of all classes as beneficial for the city. First, it establishes a venue for identifying the specialized natures of all children (especially the girls born to producers) so they can be trained to make their specialized contributions to the community. Second, it protects the city from being denied the specialized contribution of nearly half the

\footnotetext{
${ }^{26}$ Rowett, 'Philosopher Kings and the Noble Lie', p. 68.
} 
artisan adults, typically the mothers. Let's examine these twin benefits of state-sponsored child-care and education in turn.

First, it benefits the polis if those whose nature is suited for caring for and testing children have a way to access and identify all children with guardian potential. Conversely, it harms the polis if these experts do not have access to all children with the nature suited to leadership. The myth of metals includes the principle of children's potential, that an individual's potential contribution to the community cannot be inferred from the parents' nature (R. 415a-c, 423c-d). So, even if Plato's Socrates's concern were only for the guardians (as is believed by those with whom I am generally disagreeing in this essay), then he would require the existence of a state-provisioned rearing pen for the offspring of producers because future guardians ('gold' or 'silver' babies) can be found among the offspring of 'iron and bronze' people. If Plato envisions the offspring of the producer class remaining cloistered at home being brought up entirely by their parents, then the guardians who are experts at recognizing potential guardians would not be able to discover systematically and subsequently train the children with guardian potential. If these children with leadership potential go undiscovered, then the city will suffer from the loss of their contributions, violating the principle of specialization. So, the principle of children's potential would command that the guardians who are experts at discovering children's natures be able to interact with all children, especially as they play ( $R$. 536e-537a). Having the producer children cared for and educated by the expert staff at a state-sponsored center would enable the experts to ensure each child is given the education and opportunities relevant to his/her specific individual nature. Thus, the prospect of methodically finding 'gold' or 'silver' babies in the producer nursery is an important motivation to have producers' children receive care and education outside the home in a state-sponsored rearing pen.

Plato's Socrates does not explicitly construct a rearing pen for artisans' babies. However, earlier at Republic 415b-c and 423c-d, Plato suggests that some artisans' babies will join the guardians' babies at that rearing pen for gold-natured babies. There is nothing in the Republic to suggest there could not be a rearing pen for the producers' offspring. Whether it were a communal rearing pen for all babies or separate rearing pens oriented by parents' social class, such an institution would be an ideal location for testing the artisans' children for guardian potential. In fact, Plato's Socrates mysteriously alludes to the existence 
of a separate rearing pen when he tells Glaucon there will be another place, "secret and unknown" to guardians, for "the children of inferior parents, or any child of the others that is born defective" (R. 460c). Does this mean that there is one state-provided care center for guardians' babies as well as the children of the 'bronze' and 'iron' who eventually exhibit 'gold' or 'silver' natures and a separate state-provided care center for producers' babies as well as the children of other metals who eventually exhibit 'iron' or 'bronze' natures? Perhaps. If there is a rearing pen experience for producer children, then the guardian rearing experts could care for and test these babies and children and transfer those with guardian potential to the guardian rearing pen, in accord with Socrates's remarks at 415b-c and 423cd. Interestingly, in the Timaeus's summary of the Republic conversation Plato gives no details but appears to presume two parallel child-care centers when he has Socrates indicate that the inferior babies who were "secretly handed on to another city" "should be constantly watched as they grew up, so that the ones that turned out deserving might be taken back again and the ones they kept who did not turn out that way should change places with them" (Ti. 19a).

Spelman agrees with me that Plato's Socrates must envision some education and testing of artisan children, even though he does not explicitly announce a producer-class rearing pen in the Republic. Spelman writes, "All children will receive the same initial education (there is no way of telling at birth what kind of nature a person has, so all should be educated up to the point at which differences among them emerge), but only those who pass such tests can be established as philosopher-rulers (Republic 414a, 503a)". ${ }^{27}$ In contrast, Meyer presumes that there is not a mechanism in the Kallipolis for making good on the promise that every child with a guardian nature will be discovered and assigned to the guardian class. ${ }^{28}$ She writes:

...unless the entire population of the city receives this training - the children of artisans and guardians alike - these testing institutions are insufficient to make good on the promise made to the artisans in the Myth of Metals. However, while it is clear enough that the offspring of the auxiliaries and guardians receive this education and have their mettle tested in this way, Socrates gives no indication

${ }^{27}$ Elizabeth V. Spelman, 'Hairy Cobblers and Philosopher-Queens', in Feminist Interpretations of Plato, ed. Tuana, pp. 87-107, p. 96.

${ }^{28}$ Susan Suavé Meyer, 'Class Assignment and the Principle of Specialization in Plato's Republic', Proceedings of the Boston Area Colloquium in Ancient Philosophy, 20 (2005), pp. 229-43, p. 241. 
that any offspring of the artisans will receive it, and as much as says that they do not receive it (405ab; cf. 456d). ${ }^{29}$

I take Meyer's point that it would be reasonable for Plato's Socrates to design institutions to test the potential of producer offspring, and she is correct that in constructing the city Plato's Socrates does not explicitly establish a producer-class education and testing center. However, I see no indication at any point in the Republic - even at 405a-b-that Plato's Socrates rules out the child-rearing expert guardians being in a position to observe all children, including artisan children, at play, discovering their natures and testing their mettle, and as I have indicated, there are hints to this effect.

Furthermore, having a producer-class nursery in addition to the one for the guardians will protect the producers' daughters in particular from missing their opportunity to have their guardian potential recognized and cultivated. State-provisioned care and education could better ensure that girls receive the same education and professional training as their male counterparts, compared to the arrangement of children being educated at home, where the commitment to girls' education is not guaranteed. Later in life Plato writes into the Laws that parents should not control their children's education, the state should. ${ }^{30}$ If the Kallipolis's program did not include education for the girls and boys of the producer class, then the producers' daughters would not be assured the chance to receive the same education as their male peers, given the already-existing bias that boys are more valuable and capable. Again, even if Plato were only concerned with the children who have guardian potential, he would still need a meticulous way to identify and educate all potential guardians born to producers, not just among their sons. ${ }^{31}$ Meyer underestimates Plato's commitment to discovering the would-be philosopher-monarchs who are so incredibly needed by the city.

Of course, we must bear in mind that even when girls get an 'equal' education with their male peers, this does not mean that all children are given the same upbringing. As Santas writes, "And since those who share the same pursuits should share the same education, men and women of the same pursuits should have the same education, and men and women of

\footnotetext{
${ }^{29}$ Meyer, 'Class Assignment', pp. 241-2.

${ }^{30}$ Samaras, 'Family and the Question of Women', p. 176.

${ }^{31}$ Harry and Polansky, 'Plato on Women's Natural Ability', p. 273, make a similar point.
} 
different pursuits should have different educations; just as men who have different pursuits should have different educations, and women who share the same pursuits should have the same education". ${ }^{32}$ However, if there were no provision of care and education for the children of the producer class through something like a producer rearing pen ${ }^{33}$, then producers' daughters would be especially vulnerable to being denied the opportunity to contribute to the good of the polis.

Let's turn now to the second reason for Plato to require a state-sponsored child-care system involving all classes. State-sponsored child-care and education play an interesting role in Plato's vision of women's work because it is not only the venue for discovering children's potential but also the mechanism for enabling all adults who are parents to work and contribute to their society (R. 460d).

In approaching the second reason, let's think about the domestic arrangements he has Socrates announce. Whereas Socrates tells Adeimantus that there will be a dissolution of nuclear families for the guardians $(R .423 \mathrm{e}-424 \mathrm{a})$ and that guardians will not be allowed any private currency or property (R. 416d-e, 464b), Plato has Socrates suggest that producers retain their private residences $(R .417 \mathrm{a})$, which implies preservation of nuclear families. How does the notion of a producer-class rearing pen square with producers having nuclear families in private homes? If Plato did not have Socrates require a rearing pen for producer children for at least part of the day $^{34}$, then consequently at least one parent (usually presumed to be

\footnotetext{
${ }^{32}$ Gerasimos Santas, Understanding Plato's Republic (Malden, MA: Wiley-Blackwell, 2010), p. 113.

33 Glenn R. Morrow, Plato's Cretan City: A Historical Interpretation of the Laws (Princeton: Princeton University Press, 1960), p. 130-1, describes mandatory, state-run education in the Laws as perhaps Plato's greatest innovation.

${ }^{34}$ Perhaps the producer-class rearing pen, unlike the one for guardians, is not necessarily for boarding. Children with artisan potential, who are cared for and educated at a producer-class rearing pen, could possibly return to their families at the end of the day. At $R$. $415 \mathrm{~b}-\mathrm{c}$, Plato has Socrates tell us that the children of guardians who, unlike their biological parents, have artisan potential instead should be driven "out to join the craftsmen and farmers." An important question arises about these transferred children. They would not have biological families among the producer class, although the myth claims all people are related (R. 415a-b). Would the producer-class rearing pen have some children boarding full-time in lieu of a nuclear family experience? Or would the lack of unity therein be problematic enough for Plato to require that none of the children at this rearing pen go home to their private residences at the end of the day? Or would he require a system of welcoming those transferred children into producer families through adoption? Plato did not have Socrates get far enough into these details of life in the Kallipolis for us to understand his picture of life for iron or bronze offspring from gold or silver parents.
} 
the mother) would be needed to care for and educate the children at home. Okin presumes that producer's wives must stay home with children because the private home and nuclear family are intact in that segment of the city, and consequently she concludes that Plato does not extend equality to producer women. ${ }^{35}$ Okin bases her conclusion here about the Kallipolis limiting producers' wives to being home-makers on the existence of private residences for producers. However, if, as Okin suspects, mothers are expected to focus on child-rearing (as has almost always been the case in the past as well as in the present), then being kept from a specialized occupation would violate both the principle of the irrelevance of reproductive differences for non-reproductive labor and the principle of specialization, which as I have already demonstrated, Plato's Socrates explicitly extends to all women (R. 369e, 433d). Plato's Socrates would reject this as unjust.

In the Laws, Plato has the Athenian lament what a disaster it is for the community to leave women's contributions untapped. He exclaims, "I maintain that if these results can be achieved, the state of affairs in our corner of Greece, where men and women do not throw all their energies into the same activities, is absolutely stupid. Almost every state, under present conditions, is only half a state, and develops only half its potentialities, whereas with the same cost and effort, it could double its achievement. Yet what a staggering blunder for a legislator to make!" (L. 804d-805b). ${ }^{36}$ Without a state-sponsored child-care and education system that reaches all children across class, the Kallipolis would be deprived of the talents of a slightly smaller segment of the community than the full half mentioned in the Laws. Producer mothers would be denied the chance to offer their specialized talent to the polis. If there were not a rearing pen for the producers' babies and children, then regardless of which parent would be responsible for child-care and education, the parent's obligations to the child(ren) would supplant the ability to contribute to the community through a producer specialization, such as being a doctor, cobbler, or weaver.

To avoid this, the producer class could maintain private families and simultaneously have both parents contribute their special talents to the community if the state organizes a care and educational center for their children like the one that frees up guardians for their

\footnotetext{
${ }^{35}$ Okin, 'Philosopher Queens', p. 360.

${ }^{36}$ Trevor J. Saunders, trans., Laws, in Plato Complete Works, ed. Cooper, pp. 1318-1616.
} 
work. Hence, the second reason for Plato to consider a producer-class rearing pen necessary is that only with such a center can the principle of specialization be properly applied to every adult in the community instead of excluding half of all producer parents. In this way, the necessity to adhere to the principle of specialization empowers producer women to pursue a specialized occupation in addition to having children.

One final issue remains for consideration concerning Plato's treatment of artisan women. What type of education do the girls and women with artisan potential receive? To answer this question, we must assess how fine-grained Plato's conception of an artisan's nature is. Republic 455b-c defines what it means to have a particular nature, concentrating on the ability to learn easily and independently. Do the same women who will learn carpentry easily and independently learn medicine easily and independently? Even though Bluestone generally denies that women of the artisan class would be given equal education and opportunity in the scheme of the Republic, she does admit that "if we are 'presuming' on the basis of his total view, we would have to presume that potters' wives would also have to do whatever their nature fitted them for. If they had an aptitude for pottery and instead did only weaving, this, in Plato's view, would be unjust". ${ }^{37}$ Despite my overall disagreement with Bluestone, I agree with her here that, for Plato, a potter's nature differs from a weaver's.

However, Plato complicates his position when he has Socrates and Glaucon agree that it will not do "great harm to the city" "if a carpenter attempts to do the work of a cobbler, or a cobbler that of a carpenter, or they exchange their tools or honors with one another, or if the same person tries to do both jobs, and all other such exchanges are made" (R. 434a). One might object that this indicates the interlocutors' rejection of the fine-grained picture of artisan natures. Instead, we can discern from this that when producers are not doing the craft for which their talent is greatest there is some harm done to the city; it's just that Plato depicts Socrates and Glaucon as tolerant of the small harm. This comes down to their view that leadership has higher stakes than the producers' crafts; so the harm would not be tolerable in the context of soldiering or ruling. Nonetheless, Republic 434a tells us Plato believes producers have natures for specific trades, rather than a general producer nature that could be interchangeably applied to various producer crafts without any harm at all done to the

\footnotetext{
${ }^{37}$ Bluestone, Women and the Ideal Society, p. 98.
} 
community. So, when we learn that women deserve equal role opportunity even in the artisan class, we should know that their particular artisan natures need to be deciphered to determine the appropriate artisan profession through which they could make their best contribution to the community.

\section{Conclusion}

In light of textual support, I have argued for Plato's extension of equal education and professional opportunity to all women across social class, including artisan women. Scholars like N. Smith and Bluestone have suspected that Plato's principles should make him extend equal education and professional opportunity to artisan women. ${ }^{38}$ Yet, we have now seen that Plato's Socrates has an explicit vision of extending equal education and professional training to women across social class. To defend my reading, I drew attention to Plato's explicit writing in the Laws, Republic, and Timaeus about female artisans, which has been neglected. Furthermore, I showed that extending equal education and professional opportunity to all women across social class is required by Plato's theory of justice and its attendant principles, such as the principle of specialization, the principle that reproductive differences are irrelevant to non-reproductive work, and the principle in the myth of metals concerning children's potential. Plato's meritocratic vision explicitly applies these principles to female artisans as well as to the elite female guardians. Plato uses his Socrates and the Athenian to argue explicitly against gender discrimination because such discrimination harms the city by violating the principles (1) of specialization, (2) of the irrelevance of reproductive difference to non-reproductive work, and, (3) of children potentially having different natures than their parents. Plato particularly emphasizes the civic value of eliminating gender discrimination.

Even with the evidence I have marshalled here, it is fair to wish Plato would have made his commitment to equal education and professional opportunity for all women across social class even more obvious. Why did he not spend more time in the dialogues making his position about gender and justice even clearer? Plato may have considered equal education and professional opportunity for artisan women less important to address at length because

\footnotetext{
${ }^{38}$ Smith, 'Plato and Aristotle', p. 467 n. 1.
} 
it was less controversial than the idea of female leadership in politics and the military, given that women were already involved in trades and professions, including medicine. It was already more typical to see artisan women outside the home, working the fields or trading in the agora, as they were less segregated than elite women. ${ }^{39}$ So, Plato may have assumed he should direct his attention toward equality of education and opportunity for women who would be community leaders instead, given what a completely alien concept that was to his audience. In focusing on guardian women Plato makes rational, courageous, temperate women seem more conceivable and real, which is still imperative even now. Furthermore, Plato may have thought it was less important to be clearer about artisan women needing the same opportunities as artisan men if he considered it a conclusion that would follow easily once guardian women were established.

Given his belief that women could have talents for pursuits from which they were barred, Plato was a true visionary. ${ }^{40}$ Plato offering a theory of equal opportunity for women across all classes ought to be highlighted as one of the central achievements of the Republic. How extraordinary that Plato managed to imagine female leaders under the material conditions of an Athens that did not formally educate girls, that tended to constrain elite women and girls except where sanctioned by work ${ }^{41}$ or religion ${ }^{42}$, that typically married off

\footnotetext{
${ }^{39}$ Bluestone, Women and the Ideal Society, p. 105. Patterson, 'Other Sorts', p. 166, also mentions female metics.

${ }^{40}$ See also Gerasimos Santas, 'Justice, Law, and Women in Plato's Republic', Philosophical Inquiry, 27 (2005), pp. 25-37, p. 32, p. 34.

${ }^{41}$ It is often forgotten that Athenian women typically worked outside the home in a variety of occupations. For accounts of the ubiquity of Athenian women involved in commercial activity, see Roger Brock, 'The Labour of Women in Classical Athens', Classical Quarterly, 44 (1994), pp. 33646, Edward E. Cohen, 'An Unprofitable Masculinity', in Money, Labour, and Land: Approaches to the Economies of Ancient Greece, ed. Paul Cartledge, Edward E. Cohen, and Lin Foxhall (New York: Routledge, 2001), pp. 100-12, pp. 105-6, David Cohen, 'The Social Context of Adultery at Athens', in Nomos: Essays in Athenian Law, ed. Paul Cartledge, Paul Millett, and Stephen Todd (Cambridge: Cambridge University Press, 1990), pp. 147-65, pp. 156-7, and Pieter Herfst, Le Travail de la Femme dans la Grèce Ancienne (Utrecht: A. Oosthoek, 1922).
}

${ }^{42}$ The public role of women in religious life is an important exception to the constraints placed on elite Athenian women. See Cynthia Patterson, 'Hai Attikai: The Other Athenians', Helios, 13 (1986), pp. 49-67, pp. 53, 55, 62-3; Cynthia Patterson, 'Other Sorts: Slaves, Foreigners, and Women in Periclean Athens', in The Cambridge Companion to the Age of Pericles, ed. Loren J. Samons (Cambridge: Cambridge University Press, 2007), pp. 153-78, p. 169; David Cohen, 'The Legal Status and Political Role of Women in Plato's Laws', Revue Internationale des Droits de l'Antiquité, 34 (1987), pp. 27-40, p. 29; David Cohen, 'Seclusion, Separation, and the Status of Women in Classical Athens', Greece \& Rome, 36 (1989), pp. 3-15; Nikolaos Kaltsas and Alan Shapiro, ed., Worshipping 
fourteen- or fifteen-year-old girls to older husbands they did not necessarily choose ${ }^{43}$, that prohibited women from competing in the Olympic games, fighting in the military, voting, judging, or joining the Assembly, and that counted no women as property owners, managers, or independent inheritors. ${ }^{44}$

Nevertheless, scholars have spilled a great deal of ink over whether Plato ought to be considered a feminist. ${ }^{45}$ Even those of us who believe Plato is something like what one would today call a feminist are given pause due to the misogynist comments included at many points in his dialogues (R. 360a-b, 398e, 395c-e, 431b-c, 455b, 469d-e, 549c-e, 557c, 563b, 605ce; L. 637c, 669c, 694d-e, 731d, 774c-d, 781a, 794e, 836e, 944c; Phd. 60a, 117d-e; Alc. 121d; Ti. 42b-c, 76d, 90e, 91a-e; Tht. 176; M. 71e; Cra. 392b-d). These misogynist comments and his lack of commitment to reproductive choice in particular and freedom in general put serious strain upon arguments for the feminist nature of Plato's proposals for sexual equality, state-sponsored professional child-care, and educating and employing women alongside their male peers. With respect to those misogynist comments I agree with Levin, who argues that the corpus's misogynist comments typically do not coincide with remarks about the nature of women, from which we can infer that Plato did not take any particular shortcomings as irremediable. ${ }^{46}$ Nevertheless, it is fair to say, as Pomeroy has, that "not even Plato was capable of considering women as the true equals of men". ${ }^{47}$

Women: Ritual and Reality in Classical Athens (New York: Alexander S. Onassis Public Benefit Foundation, 2008), and Samaras, 'Family and the Question of Women', p. 186. See also Cynthia B. Patterson, The Family in Greek History (Cambridge, MA: Harvard University Press, 1998), pp. 3942. Furthermore, A.W. Gomme, 'The Position of Women in Athens in the Fifth and Fourth Centuries B.C.', Classical Philology, 20 (1925), pp. 1-25, Moses Hadas, 'Observations on Athenian Women', Classical Weekly, 39 (1936), pp. 97-100, and H.D.F. Kitto, The Greeks (New York: Penguin Books, 1951), pp. 219-36, contend that Athenian women were not despised or secluded.

${ }^{43}$ Sarah B. Pomeroy, Goddesses, Whores, Wives, and Slaves: Women in Classical Antiquity (New York: Schocken Books, 1975), p. 64.

${ }^{44}$ Patterson, 'Hai Attikai', pp. 52, 56, 62.

${ }^{45}$ See Appendix B.

${ }^{46}$ Levin, 'Women's Nature and Role', pp. 14, 25-6. See also Vlastos, 'Was Plato a Feminist?', pp. 19-20;_Okin, Western Political Thought, p. 63; Smith, 'Plato and Aristotle', p. 470; Stella Sandford, "Thinking Sex Politically: Rethinking "Sex" in Plato's Republic,' South Atlantic Quarterly, 104 (2005), pp. 613-30, p. 616; and Harry and Polansky, 'Plato on Women's Natural Ability', pp. 261-3, 267 n. 10, 271.

${ }^{47}$ Pomeroy, "Feminism in Book V', p. 34. 
Given what we know now about how the human brain operates, it should not surprise us that the first philosopher to critique gender discrimination and to defend sexual equality, equal education and opportunity for girls and women, and the implementation of statesponsored professional child-care simultaneously had prejudice against women. Whether the dialogues' misogynist remarks disqualify Plato's revolutionary proposals from making him philosophy's first feminist remains a topic for debate, largely dependent upon how one defines feminism. ${ }^{48}$ Ultimately I agree with Vlastos's call for considering Plato more remarkable not less so on account of transcending his own misogynist bias in order to arrive at his radical proposals about women and gender. ${ }^{49}$ My hope is that this essay helps Plato's readers better appreciate his ground-breaking vision of extending equal education and professional training to women across social class.

Appendix A-Scholarship pertaining to Plato's view that women can merit inclusion in the Republic's elite group of philosopher-monarchs

R.H. Crossman, Plato Today (New York: Oxford University Press, 1939), pp. 202-3, 206-7; Anne Dickason, 'Anatomy and Destiny: The Role of Biology in Plato's Views of Women', The Philosophical Forum, 5 (1973), pp. 45-53, pp. 49-50; Dorothea Wender, 'Plato: Misogynist, Paedophile, and Feminist', Arethusa, 6 (1973), pp. 75-90, pp. 75-6; W.W. Fortenbaugh, 'On Plato's Feminism in Republic V', Apeiron, 9 (1975), pp. 1-4; Martha Lee Osborne, 'Plato's Unchanging View of Women: A Denial That Anatomy Spells Destiny', The Philosophical Forum, 6 (1975), pp. 447-52, pp. 448-9; Susan Moller Okin, 'Philosopher Queens and Private Wives: Plato on Women and the Family', Philosophy and Public Affairs, 6 (1977), pp. 345-69, pp. 357-60, 364, 368; Susan Moller Okin, Women in Western Political Thought (Princeton: Princeton University Press, 1979); Christine Pierce, 'Equality: Republic V', The Monist, 57 (1973), pp. 1-11, Christine Garside Allen, 'Plato on Women', Feminist

\footnotetext{
${ }^{48}$ Most of the commentators who reject Plato's feminist status do so on the presumption that feminism is defined by liberal feminism, with its focus on individual rights and equality in the eyes of the law. Certainly it makes sense to consider someone a feminist if that person advocates for women's rights because one is concerned about fairness and the needs and desires of women. But Plato's socialpolitical philosophy does not include the notion of individual rights at all. If we predicate feminism upon individual rights or making individual women happy, Plato could never qualify. The better question is whether a communitarian eschewing individual rights could ever qualify as a feminist, and if so, what that would look like. Santas, 'Justice, Law, and Women', pp. 32-5, gives us a picture of Plato being such a feminist because "his theory of social justice does not discriminate between men and women; that is, it does not discriminate on the basis of gender when assignments of offices and other social tasks are made." See also Samaras, 'Family and the Question of Women', p. 185.
}

${ }^{49}$ Vlastos, 'Was Plato a Feminist?', p. 23. 
Studies, 2 (1975), pp. 131-8, p. 135; Julia Annas, 'Plato's Republic and Feminism', Philosophy, 51 (1976), pp. 307-21, pp. 307-8; Nell W. Senter, 'Plato on Women', Southwest Philosophical Studies, 2 (1977), pp. 4-11, pp. 7-11; Lynda Lange, 'The Function of Equal Education in Plato's Republic and Laws', in The Sexism of Social and Political Theory from Plato to Nietzsche, ed. Lorenne Clark and Lynda Lange (Toronto: University of Toronto Press, 1979), pp. 3-15, pp. 3-5; Harry Lesser, 'Plato's Feminism', Philosophy, 54 (1979), pp. 113-17; Nicholas Smith, 'The Logic of Plato's Feminism', Journal of Social Philosophy, 11 (1980), pp. 5-11; Nicholas D. Smith, 'Plato and Aristotle on the Nature of Women', Journal of the History of Philosophy, 21 (1983), pp. 467-78; Jane Roland Martin, 'Sex Equality and Education: A Case Study', in Femininity, Masculinity, and Androgyny: A Modern Philosophical Discussion, ed. Mary Vetterling-Braggin (Totowa, NJ: Littlefield, 1982), pp. 279-300; Bluestone, Women and the Ideal Society; C.D.C. Reeve, Philosopher-Kings: The Argument of Plato's Republic (Princeton, NJ: Princeton University Press, 1988), pp. 217-20; Patricia Ward Scaltsas, 'Virtue without Gender in Socrates', Hypatia, 7 (1992), pp. 126-37; Charles H. Kahn, 'Foreword', in Glenn R. Morrow, Plato's Cretan City, $2^{\text {nd }}$ edition (Princeton: Princeton University Press, 1993), pp. xvii-xxviii, p. xxvii; Gregory Vlastos, 'Was Plato a Feminist?', in Feminist Interpretations of Plato, ed. Nancy Tuana, (University Park, PA: The Pennsylvania State University Press, 1994), pp. 13-4 [originally published in Times Literary Supplement, March 17-23, 1989; page numbers refer to reprint edition]; Janet Farrell Smith, 'Plato, Irony, and Equality', in Feminist Interpretations of Plato, ed. Tuana, pp. 25-48; Trevor J. Saunders, 'Plato on Women in the Laws', in The Greek World, ed. Anton Powell (London: Routledge, 1995), pp. 591-609, pp. 602-3; Susan B. Levin, 'Women's Nature and Role in the Ideal Polis: Republic V Revisited', in Feminism and Ancient Philosophy, ed. Julie K. Ward (New York: Routledge, 1996), pp. 13-30; C.C.W. Taylor, 'The Role of Women in Plato's Republic', in Virtue and Happiness: Essays in Honour of Julia Annas (Oxford Studies in Ancient Philosophy suppl. vol.), ed. Rachana Kamtekar (Oxford: Oxford University Press, 2012), pp. 75-87, p. 77, p. 84; Thanassis Samaras, 'Family and the Question of Women in the Laws', in Plato's Laws: A Critical Guide, ed. Christopher Bobonich (Cambridge: Cambridge University Press, 2010), pp. 172-196, p. 183, 196; Chelsea Harry and Ron Polansky, 'Plato on Women's Natural Ability: Revisiting Republic V and Timaeus 41e3-44d2 and 86b1-92c3', Apeiron, 49 (2016), pp. 261-80, pp. 272-3.

Appendix B-Scholarship concerning whether Plato ought to be considered a feminist

W.K.C. Guthrie, A History of Greek Philosophy, Vol. 4, Plato: The Man and His Dialogues: Earlier Period (Cambridge: Cambridge University Press, 1975), p. 480, admits that Plato intends the Republic's proposals about equality of education and opportunity seriously, but he contends that they are nonetheless "wildly impossible." And Abigail L. Rosenthal, 'Feminism Without Contradictions', The Monist, 57 (1973), pp. 28-42, p. 32, considers Plato's feminism "exemplary and unparalleled in philosophy or political theory" but also "nearly useless." Darling, 'Are Women Good Enough?', recognizes that Plato does not bar women from guardianship if they are capable and that he proposes equal education with their male counterparts, but he defends Bloom partially, particularly the claim that Plato really thinks of guardians as male and that guardian women will have subordinate positions in the ruling class. In contrast, Pierce, 'Equality', Wender, 'Plato: Misogynist', pp. 75-6, J.R. 
Lucas, 'Because You Are a Woman', Philosophy, 48 (1973), pp. 161-171, Fortenbaugh, 'Plato's Feminism', Lesser, 'Plato's Feminism', Smith, 'Plato and Aristotle', Reeve, Philosopher-Kings, pp. 217-20, Scaltsas, 'Virtue without Gender', Smith, 'Plato, Irony, and Equality', Vlastos, 'Was Plato a Feminist?', Levin, 'Women's Nature and Role', Samaras, 'Family and the Question of Women', p. 187, and Harry and Polansky, 'Plato on Women's Natural Ability', take the claims about equal education and opportunity for guardian women very seriously and see Plato's defense of some feminist principles as successful, whereas Annas, 'Plato's Republic and Feminism', and Lange, 'Equal Education', pp. 3-5, take Plato's claims seriously, but for different reasons they think that his commitments fall short of qualifying as feminist, given their rights-oriented definition of feminism. G.E.M. de Ste. Croix, The Class Struggle in the Ancient Greek World from the Archaic Age to the Arab Conquests (Ithaca: Cornell University Press, 1981), pp. 557-8 n. 30, sides with Annas, who notes Plato's persistent failure to express interest in women's psychology and that Plato's sole reason for his extension of equal education and opportunity to guardian women is for the good of the state not for the freedom or happiness of individual women. Similarly, Sarah B. Pomeroy, 'Feminism in Book V of Plato's Republic', Apeiron, 8 (1974), pp. 33-5, and Catherine Gardner, 'The Remnants of the Family: The Role of Women and Eugenics in Republic V', History of Philosophy Quarterly, 17 (2000), pp. 217-35, contend that Plato has revolutionary ideas (such as recognizing that greater physical strength is the only real advantage men typically have over women), but they are tinged with repressive misogyny (such as seeing women as communal property). McKeen, 'Why Women Must Guard', Okin, 'Philosopher Queens', Okin, Western Political Thought, Brian Calvert, 'Plato and the Equality of Women', Phoenix, 29 (1975), pp. 231-43, and Spelman, 'Hairy Cobblers', can be categorized similarly to Pomeroy because they see Plato as a feminist who simultaneously has misogynist inclinations. Chadwick, 'Feminism and Eugenics', also sees tensions with Plato's feminism, particularly with his eugenics program, whereas Okin, 'Philosopher Queens', p. 360, worries about some inconsistences in his feminism such as leaving nuclear families intact among the producer class. Okin, 'Philosopher Queens' and Western Political Thought, also expresses concern that Plato's feminism is often not explicit enough. Meanwhile, Bluestone, Women and the Ideal Society, p. 96, interprets Plato as a feminist, though underdeveloped by contemporary standards, who makes more of a contribution to feminism than commentators such as Annas claim. In contrast, Jean Bethke Elshtain, Public Man, Private Woman: Women in Social and Political Thought (Princeton: Princeton University Press, 1981), Morag Buchan, Women in Plato's Political Theory (New York: Routledge, 1999), pp. 123, 157, and Mary O'Brien, The Politics of Reproduction (New York: Routledge \& Kegan Paul, 1981), p. 148, are critical of Plato's elimination of the nuclear family for the guardians, which they interpret as an affront to women and femininity. ${ }^{50}$

Coleen P. Zoller Susquehanna University

\footnotetext{
${ }^{50}$ I am grateful to Jeff Turner, Cindy Patterson, Richard Patterson, Eva Cadavid, Anne Mamary, Catherine McKeen, Sophia Stone, and the students in my 2019 Plato seminar at Susquehanna University for helpful feedback on this paper.
} 


\section{References}

Allen, Christine Garside. 'Plato on Women.' Feminist Studies 2 (1975): 131-8.

Annas, Julia. 'Plato’s Republic and Feminism.' Philosophy 51 (1976): 307-21.

Bloom, Allan, trans. The Republic of Plato, with Notes and Interpretive Essay. New York: Basic Books, 1968.

Bluestone, Natalie Harris. 'Why Women Cannot Rule: Sexism in Plato Scholarship.' In Feminist Interpretations of Plato, edited by Nancy Tuana, 109-30. University Park, PA: The Pennsylvania State University Press, 1994.

Bluestone, Natalie Harris. Women and the Ideal Society: Plato's Republic and Modern Myths of Gender. Amherst: The University of Massachusetts Press, 1987.

Brock, Roger. 'The Labour of Women in Classical Athens.' Classical Quarterly 44 (1994): 336-46.

Calvert, Brian. 'Plato and the Equality of Women.' Phoenix 29 (1975): 231-43.

Chadwick, Ruth. 'Feminism and Eugenics: The Politics of Reproduction in Plato's Republic.' In Polis and Politics: Essays in Greek Moral and Political Philosophy, edited by Andros Loizou and Harry Lesser, 101-10. Aldershot: Avebury, 1990.

Coby, Patrick. 'Minding Your Own Business: The Trouble with Justice in Plato's Republic.' Interpretation 31 (2003): 37-58.

Cohen, David. 'The Social Context of Adultery at Athens.' In Nomos: Essays in Athenian Law, edited by Paul Cartledge, Paul Millett, and Stephen Todd, 147-65. Cambridge: Cambridge University Press, 1990.

Cohen, David. 'Seclusion, Separation, and the Status of Women in Classical Athens.' Greece \& Rome 36 (1989): 3-15.

Cohen, David. 'The Legal Status and Political Role of Women in Plato's Laws.' Revue Internationale des Droits de l'Antiquité 34 (1987): 27-40.

Cohen, Edward E. 'An Unprofitable Masculinity.' In Money, Labour, and Land: Approaches to the Economies of Ancient Greece, edited by Paul Cartledge, Edward E. Cohen, and Lin Foxhall, 100-12. New York: Routledge, 2001.

Cooper, John M., ed. Plato Complete Works. Indianapolis: Hackett Publishing, 1997.

Crombie, I.M. An Examination of Plato's Doctrines. New York: Humanities Press, 1962.

Crossman, R.H. Plato Today. New York: Oxford University Press, 1939.

Darling, John. 'Are Women Good Enough? Plato's Feminism Re-Examined.' Journal of Philosophy of Education 20 (1986): 123-8.

de Ste. Croix, G.E.M. The Class Struggle in the Ancient Greek World from the Archaic Age to the Arab Conquests. Ithaca: Cornell University Press, 1981.

Dickason, Anne. 'Anatomy and Destiny: The Role of Biology in Plato's Views of Women.' The Philosophical Forum 5 (1973): 45-53.

Elshtain, Jean Bethke. Public Man, Private Woman: Women in Social and Political Thought. Princeton: Princeton University Press, 1981.

Fortenbaugh, W.W. 'On Plato's Feminism in Republic V.' Apeiron 9 (1975): 1-4. 
Gardner, Catherine. 'The Remnants of the Family: The Role of Women and Eugenics in Republic V.' History of Philosophy Quarterly 17 (2000): 217-35.

Gomme, A.W. 'The Position of Women in Athens in the Fifth and Fourth Centuries B.C.' Classical Philology 20 (1925): 1-25.

Grube, G.M.A., trans. Republic, revised by C.D.C. Reeve. In Plato Complete Works, edited by John M. Cooper, 971-1223. Indianapolis: Hackett Publishing, 1997.

Guthrie, W.K.C. A History of Greek Philosophy. Vol. 4. Plato: The Man and His Dialogues: Earlier Period. Cambridge: Cambridge University Press, 1975.

Hadas, Moses. 'Observations on Athenian Women.' Classical Weekly 39 (1936): 97-100.

Harry, Chelsea, and Ron Polansky. 'Plato on Women's Natural Ability: Revisiting Republic V and Timaeus 41e3-44d2 and 86b1-92c3.' Apeiron 49 (2016): 261-80.

Herfst, Pieter. Le Travail de la Femme dans la Grèce Ancienne. Utrecht: A. Oosthoek, 1922.

Kaltsas, Nikolaos, and Alan Shapiro, ed. Worshipping Women: Ritual and Reality in Classical Athens. New York: Alexander S. Onassis Public Benefit Foundation, 2008.

Kitto, H.D.F. The Greeks. New York: Penguin Books, 1951.

Lange, Lynda. 'The Function of Equal Education in Plato's Republic and Laws.' In The Sexism of Social and Political Theory from Plato to Nietzsche, edited by Lorenne Clark and

Lynda Lange, 3-15. Toronto: University of Toronto Press, 1979.

Lesser, Harry. 'Plato’s Feminism.' Philosophy 54 (1979): 113-17.

Levin, Susan B. 'Women's Nature and Role in the Ideal Polis: Republic V Revisited.' In Feminism and Ancient Philosophy, edited by Julie K. Ward, 13-30. New York: Routledge, 1996.

Lucas, J.R. 'Because You Are a Woman.' Philosophy 48 (1973): 161-171.

Martin, Jane Roland. 'Sex Equality and Education: A Case Study.' In Femininity, Masculinity, and Androgyny: A Modern Philosophical Discussion, edited by Mary Vetterling-

Braggin, 279-300. Totowa, NJ: Littlefield, 1982.

McKeen, Catherine. 'Why Women Must Guard and Rule in Plato's Kallipolis.' Pacific Philosophical Quarterly 87 (2006): 527-48.

Meyer, Susan Suavé. 'Class Assignment and the Principle of Specialization in Plato's Republic.' Proceedings of the Boston Area Colloquium in Ancient Philosophy 20 (2005): 229-43.

Mikalson, Jon D. Athenian Popular Religion. Chapel Hill: The University of North Carolina Press, 1983.

Morrow, Glenn R. Plato's Cretan City: A Historical Interpretation of the Laws. Princeton: Princeton University Press, 1960.

O’Brien, Mary. The Politics of Reproduction. New York: Routledge \& Kegan Paul, 1981.

Okin, Susan Moller. Women in Western Political Thought. Princeton: Princeton University Press, 1979.

Okin, Susan Moller. 'Philosopher Queens and Private Wives: Plato on Women and the Family.' Philosophy and Public Affairs 6 (1977): 345-69.

Osborne, Martha Lee. 'Plato's Unchanging View of Women: A Denial That Anatomy Spells Destiny.' The Philosophical Forum 6 (1975): 447-52. 
Patterson, Cynthia. 'Other Sorts: Slaves, Foreigners, and Women in Periclean Athens.' In The Cambridge Companion to the Age of Pericles, edited by Loren J. Samons, 153-78. Cambridge: Cambridge University Press, 2007.

Patterson, Cynthia B. The Family in Greek History. Cambridge, MA: Harvard University Press, 1998. Patterson, Cynthia. 'Hai Attikai: The Other Athenians.' Helios 13 (1986): 49-67.

Pierce, Christine. 'Equality: Republic V.' The Monist 57 (1973): 1-11.

Pomeroy, Sarah B. Goddesses, Whores, Wives, and Slaves: Women in Classical Antiquity. New York: Schocken Books, 1975.

Pomeroy, Sarah B. 'Feminism in Book V of Plato's Republic.' Apeiron 8 (1974): 33-5.

Rankin, H. D. Plato and the Individual. London: Methuen, 1964.

Reeve, C.D.C. 'The Naked Old Women in the Palaestra.' In Plato's Republic: Critical Essays, edited by Richard Kraut, 129-41. Lanham, MD: Rowman and Littlefield, 1997.

Reeve, C.D.C. Philosopher-Kings: The Argument of Plato's Republic. Princeton, NJ: Princeton University Press, 1988.

Rosenthal, Abigail L. 'Feminism Without Contradictions.' The Monist 57 (1973): 28-42

Rosenthal, E.I.J., ed. Averroës Commentary on Plato's Republic. Cambridge: Cambridge University Press, 1966.

Rowett, Catherine. 'Why the Philosopher Kings Will Believe the Noble Lie.' Oxford Studies in Ancient Philosophy 50 (2016): 67-100.

Samaras, Thanassis. 'Family and the Question of Women in the Laws.' In Plato's Laws: A Critical Guide, edited by Christopher Bobonich, 172-196. Cambridge: Cambridge University Press, 2010.

Sandford, Stella. “Thinking Sex Politically: Rethinking "Sex" in Plato's Republic.' South Atlantic Quarterly 104 (2005): 613-30.

Santas, Gerasimos. Understanding Plato's Republic. Malden, MA: Wiley-Blackwell, 2010.

Santas, Gerasimos. 'Justice, Law, and Women in Plato's Republic.' Philosophical Inquiry 27 (2005): 25-37.

Saunders, Trevor J., trans. Laws. In Plato Complete Works, edited by John M. Cooper, 1318-1616. Indianapolis, IN: Hackett Publishing, 1997.

Saunders, Trevor J. 'Plato on Women in the Laws.' In The Greek World, edited by Anton Powell, 591-609. London: Routledge, 1995.

Saxonhouse, Arlene. 'The Philosopher and the Female in the Political Thought of Plato.' In Feminist Interpretations of Plato, edited by Tuana, 67-85. University Park, PA: The Pennsylvania State University Press, 1994.

Scaltsas, Patricia Ward. 'Virtue without Gender in Socrates.' Hypatia 7 (1992): 126-37.

Senter, Nell W. 'Plato on Women.' Southwest Philosophical Studies 2 (1977): 4-11.

Smith, Janet Farrell. 'Plato, Irony, and Equality.' In Feminist Interpretations of Plato, edited by Tuana, 25-48. University Park, PA: The Pennsylvania State University Press, 1994.

Smith, Nicholas D. 'Plato and Aristotle on the Nature of Women.' Journal of the History of Philosophy 21 (1983): 467-78.

Smith, Nicholas. 'The Logic of Plato's Feminism.' Journal of Social Philosophy 11 (1980): 5-11. 
Spelman, Elizabeth V. 'Hairy Cobblers and Philosopher-Queens.' In Feminist Interpretations of Plato, edited by Tuana, 87-107. University Park, PA: The Pennsylvania State University Press, 1994.

Strauss, Leo. The City and Man. Chicago: University of Chicago Press, 1964.

Taylor, C.C.W. 'The Role of Women in Plato's Republic.' In Virtue and Happiness: Essays in Honour of Julia Annas (Oxford Studies in Ancient Philosophy suppl. vol.), edited by Rachana Kamtekar, 75-87. Oxford: Oxford University Press, 2012.

Tuana, Nancy, ed. Feminist Interpretations of Plato. University Park, PA: The Pennsylvania State University Press, 1994.

Vlastos, Gregory. 'Was Plato a Feminist?' In Feminist Interpretations of Plato, edited by Nancy Tuana, 11-23. University Park, PA: The Pennsylvania State University Press, 1994.

Wender, Dorothea. 'Plato: Misogynist, Paedophile, and Feminist.' Arethusa 6 (1973): 75-90.

Zeyl, Donald J., trans. Timaeus. In Plato Complete Works, edited by John M. Cooper, 1224-91.

Indianapolis: Hackett Publishing, 1997. 